\title{
Performance Research Seen through the Lens of Cultural Ecology: A Case Study of an Innovative Production at Chiang Mai's Lanna Wisdom School
}

\author{
Pornrat Damrhung (พรรัตน์ ดำรุง) \\ Department of Dramatic Arts, Faculty of Arts, Chulalongkorn University, \\ Bangkok, Thailand \\ dpornrat@gmail.com
}

\begin{abstract}
This paper examines a performance project called Kita Natakan Lanna (Lanna Music and Dance) done by the artist, Saran Suwanachote, or Khru Nick, a dancer in the Northern martial dance form of "Choeng," at the local arts and culture center known as the Lanna Wisdom School in Chiang Mai. By working with Khru Nick and observing how he produced a new work for this project, I learned that he used an approach based on a local form of cultural life made of interconnected parts, and used the concept of Rabob Niwet or "ecology." This system is used to transmit distinct forms of local "wisdom," including artistic knowledge, in Northern Thailand. This ecosystem approach is being used to develop innovative and sustainable ways to include performance practices and knowledge in projects linking Bangkok's universities to local urban communities with support from Chulalongkorn University's new Research Cluster in the Arts and Culture.
\end{abstract}

\section{Keywords}

performance research - cultural ecology - Lanna culture - dance - Chiang Mai Choeng

บทคัดย่อ

มองวิจัยการแสดงผ่านนิเวศวัฒนธรรม: กรณีศึกษาผลงานนวัตกรรมการแสดงทีโฮงเฮียน สืบสานภูมิปัญญาล้านนา 
บทความนี้ศึกษาโครงการการแสดงที่ชื่อว่า “คีตะนาฎการล้านนา” (ดนตรีและนาฏศิลป์ล้านนา) โดยศิลปินศรัณ สุวรรณโชติ หรือครูนิค ช่างฟ้อนในแบบศิลปะการต่อสู้ภาคเหนือทีเรียกว่า “ เจิง” จัดขึ้นที่ศูนย์ศิลปวัฒนธรรมท้องถิ่น ที่รู้จักกันในนามของ โรงเรียนภูมิปัญญาล้านนา จังหวัด เชียงใหม่ จากการทำงานร่วมกับครูนิคและเฝ้าสังเกตแนวทางในการสร้างสรรค์ผลงานใหม่สำหรับ โครงการนี้ ข้าพเจ้าได้เรียนรู้ว่าครูนิคใช้การเชื่อมโยงวัฒนธรรมท้องถิ่นหลายรูปแบบกับ ระบบ นิเวศ หรือ “นิเวศวิทยา” ระบบนี้ใช้ในการถ่ายทอด “ภูมิปัญญาท้องถิ่น” หลายลักษณะรวมถึงความ รู้ทางศิลปะในภาคเหนือของไทย ต่อมาข้าพเจ้าได้นำระบบนี้มาพัฒนาเป็นนวัตกรรมเพื่อสร้าง ความยั่งยืน ในการปฏิบัติงานการแสดงและพัฒนาภูมิรู้ในการทำงาน เพื่อเชื่อมโยงมหาวิทยาลัยใน กรุงเทพฯ กับชุมชนเมืองโดยได้รับการสนับสนุนจากคลัสเตอร์วิจัยใหม่ด้านศิลปวัฒนธรรมของ จุฬาลงกรณ์มหาวิทยาลัย

\section{Introduction $^{1}$}

This paper focuses on a performing arts project with Saran Suwanachote at the Lanna Wisdom School in Chiang Mai, Thailand in 2017 and 2018. ${ }^{2}$ Work on this project helped me to see how Thai local arts operate in a larger cultural ecosystem, and to understand how doing cultural work or artistic research is part of a larger locally-grounded living assemblage. More importantly, by seeing this project in a new way, I was able to shift my thinking so I could see artistic networks and performance-making processes as part of cultural ecologies in urban spaces, too. This new thinking has shaped work now being done in the new Chulalongkorn University Research Cluster in Arts and Culture begun in late $2018 .^{3}$

The project at the focus of this paper was called "Kita Natakan Lanna" (Lanna Music and Dance). It was the only one of the eight TRF-funded projects to be led by a young traditional dancer without current university connections. ${ }^{4}$ The main artist leading this project, Saran Suwanachote-Khru Nick or Master Saran-teaches the Northern martial dance form of "Choeng," a type of stylized northern martial arts performance, in a local arts and culture center known as the Lanna Wisdom School, located on the outskirts of Chiang Mai City. ${ }^{5}$

1 See the photos of this article at the URL https://doi.org/10.6o84/mg.figshare.13265405.

2 The research project was funded by the Thailand Research Fund (TRF) project in 2016-2019 under the umbrella "Performance Research: Doing Creative Research in Contemporary Thai Performing Arts" (RTA 5980010). The Thailand Research Fund (TRF) was merged into the new organization Thailand Science Research and Innovation (TSRI) in mid-2019.

3 This support came from the research cluster called "Cultural Ecologies of Performance: Creativity, Research and Innovation" (761008-02AC) funded by Chulalongkorn University from 2019.

4 Saran Suwannachote and Pornrat Damrhung were the co-researchers in this project.

5 The Lanna Wisdom School is a private arts center and cultural school founded in 1997. It is located at No 35, Rattanakosin Rd. Wat Kate sub-district. Muang District, Chiang Mai. 
As the co-researcher for this project, I worked with Khru Nick at the Lanna Wisdom School in 2017-2018. By observing over time the classes and working practices of Khru Nick and his colleagues that produced the new work for this project, I gradually learned that the practices and concepts used there were interconnected parts of a local cultural ecology distinct to the School and the region. Khru Nick's "Choeng" and the other art forms taught at the School are grounded in the concept of Rabob Niwet or "ecology," which they use to refer to the system of transmitting distinct forms of local "wisdom," including artistic knowledge, in Lanna - Northern Thai - cultural life. ${ }^{6}$ The transmission and training practices used in this center aimed to promote new platforms for working with young students through the local performance-practice regimen which sought to produce a different cultural environment at the school and in the surrounding community. I realized that the School and the educational platform bridged old and new thinking on the artistic practice, and created cross-generational and intra-active networks of artist-practitioners that could sustainably keep the arts alive in local Lanna society, and therefore in today's world. The ecological approach to the arts used in this school even provided access to a career-oriented path for some students into the modern urban cultural ecosystem. How did this process of transmission work? In what context did it take place? These are the questions this article seeks to answer.

\section{Performance Research: A New Platform for Artists and Arts Practitioners to Work in the Education System}

"Performance research" is a broad and fairly new set of approaches for doing artistic research in the field of performance. ${ }^{7}$ One key focus of this type of research is to seek what Julian Klein (2017) calls new "felt knowledge" and to do so by inquiring into some specific aspect of performance practice through the process of preparing, doing and staging performance work. (see Nelson 2013; Arlander, et al., 2018). This research is done by examining some specific question and material tied to artistic and theoretical work in the performance

It serves as a platform or space for people in Northern Thailand, known as Lanna, to become more connected to and involved in diverse activities tied to their local identity. They focus on practicing, teaching, learning and performing fourteen kinds of arts to embody and reproduce Lanna Wisdom, of which Fon Choeng is one important type. Khru Nick's teachings in Fon Choeng have been put into a book by his students (Wongkamdang, S. et al, 2018).

6 Thongdeelert (2017) has written about these concepts systematically and in detail.

7 Julian Klein (2017) notes that artistic research - research involving the arts - produces "sensual and physical 'embodied' knowledge" "acquired through sensory and emotional perception, through the very artistic experience from which it cannot be separated" which seeks to be "felt knowledge" which can then be used to devise new applications. 
arena, broadly conceived. It seeks to produce "embodied" and "felt knowledge" through those performance practices. It is frequently used for work done in the contemporary performing arts arena that emerges in mixed and changing cultural contexts, and likewise encourages interdisciplinary vision and international involvement. For the TRF projects, we were seeking to find ways to produce new forms of "embodied" and "felt knowledge" through integrating or infusing traditional forms, practices, stories, and artists known in Thailand with contemporary modes, settings and sensibilities in diverse communities.

As a type of creative research, performance research often uses phenomenological approaches to examine and interpret embodied encounters with and involvement in the world through performance. ${ }^{8}$ Researchers in this field examine how artistic practices animate performance and generate new "felt knowlege" by collecting data while developing performance through rehearsals and staging performances. By inquiring, discovering, and sharing their work done through performance, performance researchers study how practitioners and audiences engage with traditional and new performance ideas, methods, materials and practices through lively exchanges. It is possible to see these engagements and the new and usable embodied knowledge produced as forming distinct performance or theatre ecologies, and this perspective is precisely the one used at the Lanna Wisdom School.

Building on the work of Robin Nelson (2013), I use the word "performance" for the practices done in the performing arts, in two different senses:

1) Performance first means the acting and doing that constitute the theatremaking process. In this research project, performance is used for the productive practice processes that involve creating things by doing them, then collecting data, seeking to answer questions while working, rehearsing, preparing for doing performances, focused on the processes of producing new "felt knowledge."

2) Performance also means the acting and doing of a work onstage during a specific staging of a play, whether done by specially trained dancers, musicians or performers, whether in traditional or in modern-style

8 There are several different terms used to link research to the performing arts, with Performance Research, Practice as Research, Artistic Research, Practice-Led Research and Performance as Research among the most common. This diversity in terminology has not reached closure at present, and terms and related commitments and priorities and foci are still contested, but many of the approaches converge around the notion of "practice." I will view this interconnected array of distinct terms as sharing a kind of family resemblance, in the sense used by Ludwig Wittgenstein in his Philosophical Investigations. Nelson (2013) presents an especially clear and systematic version of the approach, which he calls "practice as research in the arts," so I find it useful for this project. 
theatre. These artist-researchers who embody their art - whatever their training or background - question something about their art in their work in their onstage performance and seek to produce some new "felt knowledge."

Performance research in this sense involves artists and others involve in the work asking questions and trying to solve problems about sensual and physical "embodied" or "felt knowledge" tied to performance-making and staging by using relevant materials and ideas tied to those performances and their audiences. Besides being based in different parts of Thailand, one unique aspect of the performance research done for the TRF projects is that it involved collaborations of those trained in Thai performance traditions working with those trained in modern performance traditions. We deliberately designed the projects in this way to produce new work that was both contemporary and rooted in traditions, and so able to generate some new "felt knowledge." That goal and process was also true of Khru Nick's project. We wanted to know how researchers who work across disciplines and between cultural traditions in research platforms could create distinctive and viable spaces and embodied knowledge for contemporary Thai performance.

Khru Nick's work and other work seen in the pieces of performance research in this special MANUSYA issue stem from different research projects that I have been involved with between 2016 and 2019 in different parts of Thailand. The projects often focused on re-interpreting old literary texts or old legends that are then retold in diverse new kinds of performances, normally through the joint efforts of those with traditional training and those with modern training. The research projects that emerged from the performance research efforts differed depending on how the artist-researcher understood and questioned traditional stories and also from the audiences' memories and reactions to them. The reactions to traditional stories in memories of artistic practice or audience memories was elaborated into research questions and approaches to solving these questions by creating new performances that could critically comment on, reflect or question old texts or understandings that could follow different directions, according to the researchers goals, with the goal of produced new forms of felt knowledge.

\section{Performance Research at the Lanna Wisdom School at a Critical} Moment of Transition

The "Kita Nartakan Lanna" project run by Khru Nick in 2017-2018 sought to create a dance-theatre piece called "Pu Nang Sang Luang" (The Great Ancestor 
Pu Nang). ${ }^{9}$ It sought to produce the new felt knowledge by asking questions of its performers and its audiences about who they are and what they are leaving behind as they moved to the unknown future which different from the old Lanna ways using legends, tales, and forms from old Lanna culture. What did they leave behind is their sense of local identity? The Lanna Wisdom School seeks to keep, embodying, transmit and renew what they called "Lanna wisdom" through teaching the performing arts and cultural practices to people. The School thus serves as a living platform for sharing, learning, exchanging and supporting each other in and through community events tied to the arts and cultural practices based in Northern Thailand and the embodied knowledge it generated.

As a Fon Cheong style martial arts artist in Chiang Mai, Thailand, Khru Nick's performance-based research sought to create a contemporary Lanna dancetheatre piece grounded in traditional Lanna arts at a temporary new open-air stage to celebrate the $20^{\text {th }}$ anniversary of the Lanna Wisdom School, founded in 1997. He aimed to develop a new environment for Lanna dance practitioners to rehearse and work in a contemporary theatre sensibility that would retrain young people in the program to be aware of their roles, their duties and responsibilities as performers in a large and complex piece, where they would work toward the project goal that they worked with their masters and other artists in the project.

The TRF provided funding to permit Khru Nick' performance to permit artist-teachers like himself and other young arts-practitioner colleagues at the School to work with young apprentices and students of all ages and levels to create a community event for its special anniversary. The key concept used for the project is the local cultural transmission system known as Hun-Hien-Hum$H u k .^{10}$ Through this system, Khru Nick sought to create a new platform which allowed his young students to experience and practice a new modern style of working in theatre that would link traditional teaching methods to modern theatre arts. This would develop different forms of training and discipline, including responsibility, focus and working together on completing a high-quality project, as well as produce enduring transferable skills everyone could further develop or use in other situations. From this modern theatre platform, Khru Nick used the interconnected system of local cultural

9 It is tied to the Tai Kuen Legend, about the spirits of the ancestors, (Pu) Grandpa and (Ya) Grandma, of Lanna northern Thailand culture (interview with Saran Suwannachote 2018) and also $\mathrm{Phi} \mathrm{Pu}-$ Ya. Also see Social Research Institute Chiang Mai University (n.d.)

10 Khru Nick uses these ideas from Thongdeelert (2017) in his teaching. These concepts have been used in the Lanna Wisdom School for twenty years. The book celebrates the school. 
practice: Hun (seeing, watching, observing), Hien (learning from different sources), Hum (sharing by doing, being involved, active participation, exchanges), and Huk (focusing on and attending to things you love to do) as the main elements to elaborated the new production of Pu Nang Sang Luang.

Through his research performance process, Khru Nick sought to pass on the core of creative learning in an familiar ecosystem for his participants and audience by creating a new performance space that would refresh traditionallytrained young apprentices and even small children as they worked and engaged in alternative type of performance as part of a group and in a different performing space using different roles than they were used to.

By building on familiar local cultural memories and developing the performance in a creative way using old forms of teaching and learning, Khru Nick created new conditions in the performance of the dance, allowing the musical score and dance choreography to include more spontaneity and creativity and to reimagine sound and dance rhythm that differed from traditional performance spaces. This performance preparation created excitement and produced a dynamic and lively attitude towards traditional art forms.

Staging the piece in a new type of outdoor theatre space allowed teachers and students to work and interact on a large ensemble piece which was new to them. ${ }^{11}$ By using limited dialogue, the performers were partners who helped move the dance, sound, and the plot forward and took responsibilities in their roles in the plays and outside with their teams. This new space gave new meaning to performers, who could communicate the important theme about the creativity of themselves and their own tradition, giving their traditional training more of a contemporary feel, helping to generate a new embodied form of knowledge.

Students involved in the piece learned the importance of doing their best on whether individually or as part of a group, whether during rehearsals or in performances, they collected the energy, the will and the discipline and hard work of the artists. They also worked with new knowledge of technology in sound and lighting, using cues, and sound interactions with teams.

$\mathrm{Pu}$ Nang Sang Luang was first performed two times at an outdoor stage on the grounds of the Lanna Wisdom School in Chiang Mai on 7-8 February, 2017. Audiences of about $25^{-}-300$ people came each time. It was later performed at Chulalongkorn University on 21-22 August, 2017. The production

11 The performance was led by two well-known Lanna artists, Khru Nick, Saran Suwannachote and Khru Ong, Ronnarong Khampha, who played the Hero and anti-Hero, respectively in the piece. The female parts were performed by young dance masters of the Lanna Wisdom School. 
had collecting the energy of parents and all school teachers and the network of young dance and music practitioners to Hum-sharing and working together during the performance. It became well-known by the audiences and it was widely reported and shared in media and through social network. As a new creation grounded in traditional artistic skills for a specific event, it also helped to solve new problems. Performances were likewise done at outside theatres, at local festival and community spaces. It was seen and heard by more than 1000 people altogether, and gave a diverse feeling and communication giving new message-images-impressions that open more for different interactions.

The project and the production of Pu Nang Sang Luang helped to change the school by including its new mode of embodied and felt performance knowledge, since it brought new approaches to performance and new forms of felt knowledge for audiences and artists alike. It was opened to new media platforms and it allowed people to know the art forms and the space more. More classes were opened for students with more opportunities for them to practice and perform arose. But the school itself still operated through the process of Hun-Hien-Hum-Huk, encouraged students to learn and to be a part of the school and to spend time practicing the arts form that best suited them.

As my understanding of the Lanna Wisdom School's Rabob Niwet or "cultural eco-system" grew, we spend more time in being with others tied to the community of the School. By collecting knowledge about how everyone learned to help out, rehearse and perform in front of different audiences, the Pu Nang Sang Luang production expanded the contemporary audience base from big cities into local communities and local events, helping to generate new interactive spaces of performance for both artists and young students. It helped revitalize the cultural ecology of the School.

The theatre space where Khru Nick created a temporary location for the production has become a new arena or "Khuang" (space) of the Lanna Wisdom School. This new space has become a new site for young practitioners to collaborate in traditional Lanna arts. It is the new venue of a new creation of dance-theatre, for speaking, painting, and for performances. It has become a new space for artists and audiences to re-commit to using old Lanna wisdom in the $21^{\text {st }}$ century. The performance event and its working process has also become a model for young apprentices to view and review, learn and re-learn and participate, sharing and collecting things that they are interested in. A venue for arts apprentices to express, sharing and learning from each other-old and new. The theatre space is becoming a place where local Lanna dancers and artists gather each month to create new performances. It has become regular part 
of the Lanna dance ecosystem, making the school and its site into a new place to showcase and create alternative forms of performance so artists can exchange and embody movements for their peers, and move towards finding new conditions for learning and performing Lanna culture, creating a new ecological space for creating new life forms, including new ways of feeling and using performance knowledge. ${ }^{12}$

The school has become famous in a different way, too. Its cultural ecosystem has helped to promote the Lanna culture in what may be a more sustainable way. This ecosystem has generated a network for young street or new hip hop style dancers in Chiang Mai who want to try Fon Choeng and to integrate Fon Choeng into hip-hop dancing trends.

What I also came to realize is that the other T RF performance research projects were, like Khru Nick's project at the Lanna Wisdom School, embedded their own cultural ecologies here in Thailand. This became clearer when I read two books about the Lanna Rabob Niwet or cultural ecosystem and its values. The first book that inspired me to think about performance cultures at work in cultural ecologies was Suebsan Lanna or Lanna Heritage by Chatchawarn Thongdeelerd, the chair of the board of the Lanna Wisdom Foundation which runs the school. Reading this book helped me to see how culture and the arts were parts of ecosystems including how people's local activities and values were bound up with their local environment.

Most of the performance-making done in the school works through the concept of Hun-Hien-Hum-Huk - living-being involved-learning and practicing with and from wisdom of the artist-masters and also includes people in their environment, and all of the things happening around them. The performing arts makes an environment where people can live, work and interact with each other in what they know and can exchange to mutually strengthen themselves. The TRF performance research work thus not only opened up diverse new areas of interaction, but it also revealed new patterns of coordination which could produce new creative work for the contemporary world.

A second perspective on cultural ecologies that provided a different way of understanding the ecologies of arts and culture beyond just emphasis on economic value was John Holden's 2015 report "The Ecology of Culture," which builds on the work done on this model for understanding the arts by Ann

12 See Damrhung (2020) for more discussion of the Lanna Wisdom School. 
Markusen (2011) The metaphor used here suggests that performance cultures worked locally through interdependent agents and processes. Like these authors, I have started to view these fertile, fragile and interconnected performance environments as performance ecologies. For Holden, and others, the ecological metaphor is useful in underscoring several often-neglected dimensions of value in the arts and culture beyond generating revenue:

a) "all parts of the cultural system are interdependent and, in this sense equal, and equally valuable: all parts are needed to make the whole;" b) "culture is a communal phenomenon, with disparate elements coming together to produce a whole; where 'audiences' create culture just as much as do 'artists'. Culture is a social process;" c) “...the cultural ecosystem is not separate from us, or related to us, but rather we are embedded in it - it makes us, at the same time as we make it. Culture is a process of constant formation, where our views and decisions are moulded by what we see, read, make, watch and listen to;" d) emphasis on holistic perspective and qualitative values; e) "If culture is treated as an ecology, then the analytical approach becomes one of identifying cultural value, by taking into account the multifaceted and pluralistic value of culture beyond, as well as including, the economic. Culture recovers its organic meaning, its social significance and its moral weight, bringing into play the health of the cultural system, its creative capacity, its ability to generate new meaning, and the social and public goods that it produces...”. (Holden 2015, 12)

The research done with Khru Nick helped me to see how arts and culture were often best seen as parts of ecological systems. This approach also provided new ways to think about working in dance and theatre, namely as interactive and interdependent artistic systems that work through processes. Rather than seeing the piece in terms of embodying the director's concept by accepting their vision and decisions, the working process is normally done in a more openended way. Through collaborative research platform, it helps to open up the director-researcher to do two things between rehearsals. First, the whole ensemble interacts, listens and communicates more with one another on the reflection and problems that occur in the development of the project, and this allows participants to reflect and interact in what they are doing and lead to alternative way to work and solve the problems. The interactive and dialogic mode also, secondly, depends on the deeper ecology of the performance and the tradition rooted in a community which provides the performers, content, and audience of the performance. By encouraging more reflective and 
interactive collaboration among researchers and artists throughout the performance-making process, they create different modes of involvement and interrelations that is best captured through the metaphor of performance ecology.

This performance ecology integrates diverse creative processes rooted in different modes of training, performances, which then generate actual examples of artistic innovation - in the form of experimental pieces emerging from new symbiotic processes - which create work in new aesthetic ecosystems. These experimental research performances create new messages drawn from old stories or cultural memories which new constellations of artists reinterpret to communicate something al to move contemporary audiences.

The research-based experimental artistic efforts considered here emerge in interactive cultural laboratories to develop and share new performance work for life. These efforts depend on new practices of collaboration, performance thinking and uses for theater work, typically beyond the walls of theatre spaces. Because of the importance of new research methodologies used here - in the field, so to speak - and due to their experimental nature of their practices and their goals of developing innovative creative that prepare people for living well, a crucial base to develop this new work in these performance ecologies is in universities. This university platform for collaborative performancecentered research work for life beyond the stage provided a venue for creating opportunities for artists, researchers, students and diverse audiences to develop their thoughts, modes of interaction, and their bodies together in new performance ecologies for life.

Urban Universities as Experimental Laboratories for Performance Ecologies

Khru Nick created and showed his performance in a School focused on the informal transmission of Lanna arts and culture, following local principles of cultural ecology based on producing new forms of lived and felt knowledge. Since I work mainly in universities, and since most of the TRF performance research projects had at least one foot in universities, we can see these university spaces as more than just spaces for teaching and learning academic knowledge. Beyond providing practical skills and new modes of thinking and feeling, including commitment to local knowledge, universities can serve as laboratories of innovation to help produce the trust and respect of different performing arts practitioners who work together and an ability to develop new ways to engage and involve the public with their performance practices. By doing new 
work together in university spaces, artist-researcher-participants learn to exchange their thoughts and practices, interacting with each other while they seek to create new performances and modes of performance together, building trust and creativity over time. The experimental laboratories offered for new work in performance in universities offer safe interactive spaces organized as cultural ecosystems, and for producing new ways of experiencing and showing knowledge. Seeing performance research as grounded in ecologies of performance for life and for producing felt knowledge offers a new perspective on how to situate the work of local artists, diverse performance practices, and new reasons to perform which can involve new audiences. This offers new opportunities to access reimagined versions of local performance in spaces and in festivals beyond theatre walls. Audiences could interact in some familiar yet different spaces, leading to new felt knowledge, critical thinking and embodied practices for performance.

Two key findings emerged from the overall TRF research projects that ran from 2016 to 2019. First, local context matters to both performance and research for the kind of felt knowledge it produces; and second, each context is shaped by diverse interdependent and evolving ensembles of people, techniques, and other resources that enable and sustain the performance processes and the way new felt knowledge can be applied in new contexts. Those two findings, seen especially strongly in the project of Khru Nick at the Lanna Wisdom School in Chiang Mai. This led me to view performance research as part of living ecological systems which produced embodied felt knowledge and significance through performance activities done by and for discrete and interconnected social groups and artistic networks, both in the university and those on the edges of universities. Researching and developing these performance ecologies has become the focus of the new research group that Chulalongkorn University chose to fund from December 2018 as part of the new research cluster focused on "Innovation in Arts and Culture."

These realizations thus generated new ways to implement applied knowledge from theatre practice in and beyond local universities, to work with artists in communities and to extend performance practices into new venues through diverse experimental efforts to combine traditional and modern performing arts. The outcomes of these performance experiments created new interaction zones where university artist-researchers and their students could directly engage local living artists who embodied local creative knowledge in their communities in generating innovative work at once relevant to creative, academic and local communities. ${ }^{13}$ We also need to consider potential new

13 See Damrhung, et al. 2019a, 2019b for some of these results. 
roles of performance in our environments and our lives especially how to engage diverse $21^{\text {st }}$ century communities, both rural and urban.

By seeing performance research as part of cultural ecologies of performance which seek to produce new lived forms of felt knowledge, we can better realize that performances are embedded in cultural ecologies, which helps to focus more on the diverse participants or stakeholders in today's cultures of performance. By performing, artists are certainly "doers," but their exchanges with other participants and with audiences who are involved in performance practice produce performance communities and ways of engaging them with embodied forms of knowing which engage the arts, permitting the arts to better communicate with people in today's world.

Many participants in the new Chulalongkorn University Research Cluster in Arts and Culture project are young theatre arts practitioners and lecturers who are seeking new performance practices, knowledge, languages, and meanings for the arts and are seeking to do this work in new spaces outside of the theatre walls in order to better connect their work and their lives to diverse communities on and around the Chula campus, including the virtual spaces and communities they inhabit and in the wider international community. Developing sustainable ecologies for performance tied to new types of felt knowledge both on and beyond the stage is the goal of the research cluster and of the July 2019 conference from which are the papers in this special issue of MANUSYA are drawn. We are also looking for ways to connect ourselves to other practitioners and groups in the region. Our concluding roundtable sessions at the conference worked through some of the key issues discussed earlier on each day. These roundtables helped to catalyze new insights, generate some new thinking, and suggest new directions and areas for collaboration.

The three years of work in performance research with nearly two dozen researchers across Thailand led me to see that their work and the resulting research was rooted in more complex and interactive forms of cultural life and felt knowledge-making rooted in communities which I have called "performance ecologies" in this paper. This realization became clear through my work with the Lanna Wisdom School in Chiang Mai, Thailand, which has both unique its own artistic ecology and a distinctive way of producing embodied knowledge, articulating and reproducing this ecology in its local community. These complex forms of live may be seen as "cultural ecologies" which Ann Markusen (2011) has defined as "the complex interdependencies that shape the 
demand for and production of arts and cultural offerings." By generating new modes of felt knowledge that can be put to work both in the university and in diverse communities beyond it, these cultural ecologies of performance are also involved in social innovation. This perspective on the arts is useful to understanding more kinds of performance in Thailand, too, and it was integrated into the new Arts and Culture Research Cluster at Chulalongkorn University which started in late 2018.

The School of Lanna Wisdom is becoming a sustainable cultural ecosystem for reproducing living performance cultures in Northern Thailand. It has existed since 1997 and it has become a vital niche for creating cultural life in the contemporary flow of in Chiang Mai. The performance research done in the $\mathrm{Pu}$ Nang Sang Luang project in 2017-2018 cemented the value of Lanna Wisdom in the community as an engaging theatre performance that reembodied the old spirit of Lanna cultural wisdom in the moving bodies of performers. The dance and the music represented the struggle in many audiences' minds about their own identities and what they would like to join in continuing the spirit of dance in this beautiful martial arts form.

Khru Nick, a "Khru Bhumpanya," has made Fon Choeng and martial arts dance into a viable form of dance knowledge and practice that he could use to creatively communicate with his performers and engage his audiences. ${ }^{14}$ The Fon Choeng dance has found a new vibrant niche for reproducing the spirit of Lanna dance in the contemporary world. By representing the scenes of the revived legendary Pu Nang - Sang Luang story with a revived working process based on old forms of learning dance, Khru Nick has been able to make Lanna dance into someting new and different and to make it matter to young people in urban Chiang Mai today. The success of the new dance ecosystem and the mode of felt knowledge it produces has started to attract more young people,

14 Khru Bhumpanya or "master of wisdom" is the name of a student in a tradition who has been given the right to teach others by another Khru Bhumpanya with whom that student has studied. It is marked by a formal ceremony done in a local community with the master and student present. After this local ceremony of master and student, it is reported to and is recognized by the Culture Ministry of Thailand. This traditional way to pass down artistic authority in various traditions has created many masters who have studied their arts in communities with local masters, rather than in the formal Thai education system. They are recognized experts in local Lanna arts whose authority rests outside the Thai school system. Their teaching is passed down by paying homage to spirit of Khru or master of that tradition. A student wanting to become a "master of wisdom" or expert in the art forms first needs to search for a master who would teach him. To be a khru Bhumpanya demands a lifelong learning and a devoted practice of the tradition. After finding a master to teach him, the student needs to live and learn from his master in a whole way of living to develop life and mind. This includes learning how to live and what not to do. It involves practice and training both in the art form and in the proper way of living. 
so the School has had to formalize, regulate and schedule the teaching and performance process. More students from urban Chiang Mai have joined the School of Lanna Wisdom since 2018.

Urban universities provide especially productive venues for examining and enhancing the cultural ecologies centered on performance and the productive forms of embodied knowledge they generate. The cultural ecologies of urban performances and the useful felt knowledge they produce form the current phase of our research. Supported by Chulalongkorn University, our new research cluster seeks to understand how diverse forms and uses of performance help to enhance new forms of complex and interdependent cultural life and lived forms of felt knowledge in cities from a university base.

These new forms of locally grounded life provide examples of how to collaborate with local artists in and around Bangkok's urban spaces to make new lived knowledge for society. Innovative work that use traditional elements to convey new meanings to connect to contemporary urban audiences can bridge to young people in local communities so they can find new meanings in old cultural forms that strengthen their identities and their capacity to live well.

Such new research spaces of performance can serve as new living experimental laboratories that are not driven solely or mainly by economic or tourist priorities. They also can nurture common living local cultures and citizens that allow new creation new work in the arts that is collaborative, interactive and able to nurture symbiotic artistic trust and respect for collective complex problem-solving in the performing arts. They moreover provide opportunities for creating embodied knowledge in project-based creative and critical thinking projects that can help diverse groups to live well and sustainably through performance in the $21^{\text {st }}$ century beyond the theater walls.

\section{Acknowledgement}

I would like to thank the two anonymous readers for their careful reading of my manuscript. Their many insightful comments and suggestions have allowed me to clarify several topics and to correct some errors. I have used them to improve the paper in many ways. I appreciate the thoughtful and useful comments from these anonymous referees.

\section{References}

Arlander, Annette, Bruce Barton, Melanie Dreyer-Lude, and Ben Spatz, eds. 2018. Performance as Research: Knowledge, Methods, Impact. New York: Routledge. 
Damrhung, Pornrat, et al. 2019a. Kham sat kham wela: wicai kan sadaeng nai withi niwet watthanatham (Cross-Disciplines, Cross-Times: Performance Research in a Cultural Ecology Approach). Supported by the Thailand Research Fund (TRF)/Thailand Science Research and Innovation (TSRI). Nontaburi: Parbpim Publisher. (In Thai).

Damrhung, Pornrat, et al. 2019b. Prakotkan kan sadaeng: mahawitthayalai nai withi niwet watthanatham (Performance Phenomenologies: University in a Cultural Ecology Approach). Supported by the Thailand Research Fund (TRF)/Thailand Science Research and Innovation (TSRI). Nontaburi: Parbpim Publisher. (In Thai).

Damrhung, Pornrat. 2020. "Refreshing the Spirit of Creativity: The Cultural Ecosystem Approach at the Lanna Wisdom School, Chiangmai." In Spirit of Creativity in Dance Education, edited by Mohd Anis MD Nor. Kuala Lumpur: Nunsantara Performing Arts Research Center.

Holden, John. 2015. The Ecology of Culture: A Report Commissioned by the Arts and Humanities Research Council's Cultural Value Project. London: AHRC.

Klein, Julian. 2017. "Reflection: 'What is Artistic Research?'” Journal of Artistic Research, posted April 23, 2017. Accessed December 28, 2019. https://www.jar-online.net/ what-artistic-research.

Markusen, Ann. 2011. California's Arts and Cultural Ecology. San Francisco: James Irvine Foundation.

Nelson, Robin. 2013. Practice as Research in the Arts: Principles, Protocols, Pedagogies, Resistances. New York: Palgrave Macmillan.

Social Research Institute Chiang Mai University.n.d. "Khwamchuea Lanna Kiaokap Mae Lae Dek” (A Lanna Belief about Mothers and Children). Accessed August 29, 2020. http://www.sri.cmu.ac.th/ elanna/lannachild/scripts/belief/belief_belief.html \#ghost (In Thai).

Suwannachote, Saran. 2018. Interview by author in Chiangmai. March 24, 2018.

Thongdeelert, Chathawan. 2017. Senthang Suebsarn Lanna (Path to Lanna Heritage). Chiangmai: Siam Pimnana. (In Thai).

Wongkamdang, S. et al. eds. 2018. Fon Choeng Fon Darp. Basic 1 (Curriculum of Saran Suwannachote). Chiangmai: Siam Pimnana (In Thai). 